\title{
ANALISIS PERILAKU ALIRAN TERHADAP KINERJA RODA AIR ARUS BAWAH UNTUK PEMBANGKIT LISTRIK SKALA PIKOHIDRO
}

\author{
Kristianus Jamlay , Luther Sule, Duma Hasan \\ Teknik Mesin, Politeknik Amamapare Timika, Jl. C. Heatubun Kwamki Baru Timika \\ Mimika Papua, Indonesia \\ *E-mail: timikaandalanku@gmail.com
}

\begin{abstract}
Energy of water is one of the renewable energy that can be converted into electrical energy without pollution. Rotation, torque, and power generated by the water wheel can be used directly both for irrigation pumping and for running a rice mill even move the alternator and electrical generators. The purpose of this study was to find the best water wheel performance indicated by torque, rotation, and power as well as the relative speed of the water at the side of the blade. The results obtained in the preliminary test were the average water velocity of 2.50 $\mathrm{m} / \mathrm{s}$, the average rotation shaft of $79.78 \mathrm{rpm}$, the average torque on the shaft of $58.98 \mathrm{Nm}$, the average power of 510,67 W. The second results were also obtained as given the results and discussion section. It was found that the best water wheel performance based on the analysis was shown in the second test results.
\end{abstract}

Keywords: water flow velocity, rotation, torque, power, relative velocity

\section{PENDAHULUAN}

Air merupakan sumber energi yang murah dan relatif mudah didapat, karena pada air tersimpan energi potensial (pada air jatuh) dan energi kinetik (pada air mengalir). Tenaga air (hydropower) adalah energi yang diperoleh dari air yang mengalir. Pemanfaatan roda air sebagai komponen utama pembangkit listrik skala kecil mulai dikembangkan khususnya pada daerah-daerah aliran air yang dangkal dan head yang cenderung rendah (Sule, 2011). Tinggi air jatuh (head) yang bisa digunakan kincir atau roda air ialah $0,1 \mathrm{~m}$ sampai $12 \mathrm{~m}$ (Dietzel, 1996). Mengingat tinggi jatuh air (head) yang ada di desa Tamangil Nuhuten cenderung rendah maka salah satu cara yang bisa dilakukan untuk mengubah energi air tersebut ke energy listrik yaitu dengan memanfaatkan kincir air atau dalam penelitian ini disebut roda air (water wheel). Jika ditinjau dari arah aliran air yang menghantam sudu, maka roda air dibedakan menjadi roda air arus atas (overshot water wheel), roda air arus bawah (undershot water wheel), breatshot water wheel, dan tub water wheel. Dengan memperhatikan kondisi aliran air di desa Tamangil Nuhuten maka dalam penelitian ini digunakan roda air arus bawah (undershot water wheel) karena sekalipun head yang rendah roda air jenis ini masih bisa beroperasi.

Sebelum perancangan roda air arus bawah untuk pembangkit listrik skala piko hidro, terlebih dahulu perlu menganalisa perilaku aliran di saluran. Perilaku aliran yang dimaksudkan di sini adalah suatu fenomena pada aliran air salah satunya yaitu kemungkinan terjadi perubahan kecepatan dan dampak yang ditimbulkan terhadap putaran, torsi, daya, serta kecepatan relative air tersebut terhadap sudu baik pada sisi masuk (entry side) dan sisi keluar (exit side) roda air yang direncanakan.

Sihombing (2009) melakukan suatu penelitian pengujian sudu lengkung turbin air terapung pada aliran sungai dimana dari hasil pengukuran diperoleh kecepatan air masuk $1,75 \mathrm{~m} / \mathrm{s}$ dan setelah dianalisis secara teoritis diperoleh putaran $\left(\mathrm{n}_{\mathrm{p}}\right) 29 \mathrm{rpm}$ dan daya $\left(\mathrm{P}_{\mathrm{Ra}}\right)$ $125,97 \mathrm{~W}$ serta kecepatan relative pada sisi masuk sudu $\left(W_{1}\right) 0,61 \mathrm{~m} / \mathrm{s}$, pada sisi keluar $\left(W_{2}\right) 1,29 \mathrm{~m} / \mathrm{s}$ dan sudut $\beta_{2}$ (antara $W_{2}$ dan $\mathrm{U}_{2}$ ) ialah $28^{\circ}$. Mangkau (2013) melakukan suatu penelitian tentang kinerja roda air aliran bawah sudu lengkung untuk pembangkit listrik dimana pengukuran kecepatan air dilakukan pada saluran datar di laboratorium (tanpa head dinamis) dan memperoleh debit air $(Q)$ $0,0135 \mathrm{~m}^{3} / \mathrm{s}$, daya maksimum $(\mathrm{P}) 14,47621$ Watt serta efisiensi maksimum (n) 22,299 \%

Perbedaan yang muncul antara penelitian ini dengan penelitian sebelumnya ialah bahwa model sudu yang direncanakan di sini adalah sudu bengkok, menggunakan saluran buatan dan terbuka, ada head dinamis dan kecepatan aliran air divariasikan serta dilanjutkan dengan analisis putaran, torsi dan daya roda air serta kecepatan 
relative air terhadap sudu pada sisi masuk dan keluar berdasarkan perubahan kecepatan aliran air tersebut dan setelah data-data tersebut diperoleh selanjutnya ditarik suatu kesimpulan bahwa hasil pengujian mana yang akan digunakan sebagai data sekunder untuk perancangan roda air arus bawah sebagai pembangkit listrik skala pikohidro sedangkan pada penelitian terdahulu (penelitian pertama dan kedua) dimana penelitian pertama menggunakan sudu lengkung, memanfaatkan aliran air di sungai dengan head dinamis, kecepatan air tidak divariasikan serta tidak ada analisa torsi dan pada penelitian kedua menggunakan sudu lengkung, memanfaatkan aliran air buatan (air dipompakan) tanpa head dinamis, kecepatan air tidak divariasikan serta tidak ada analisa torsi. Dengan kondisi semacam ini sulit disimpulkan bahwa kecepatan tersebutlah yang terbaik serta perilakunya terhadap putaran, torsi, daya dan kecepatan relatif air terhadap sudu roda air.

\section{FASILITAS DAN METODE PENELITIAN Skema Alat Penelitian}

Penelitian ini menggunakan peralatan sederhana khususnya dalam pengukuran kecepatan aliran air yang secara skematis disketsakan pada gambar 1. Awalnya saluran air diletakan pada posisi yang sudah ditentukan kemudian pintu saluran air dibuka secara perlahan-lahan sampai kondisi bukaan penuh dan sementara itu air dibiarkan mengalir tanpa perlakuan hingga kondisi aliran air di saluran stabil. Untuk mencapai kondisi dimaksud, waktu yang dibutuhkan \pm 10 menit.

Setelah aliran air mencapai kondisi stabil, mulailah dengan pengukuran kecepatan air. Untuk mengetahui kecepatan aliran air di saluran, metode yang digunakan adalah metode manual dengan cara melemparkan benda terapung berupa sebuah pelampung ke aliran air dalam saluran dengan jarak tertentu kemudian dibagi dengan kecepatan benda menempuh jarak tersebut menggunakan stopwatch. Pengujian dilakukan beberapa kali dengan waktu yang berbeda.

Pintu air dan saluran terbuat dari papan dimana tebal papan yang digunakan $2 \mathrm{~cm}$. Ukuran pintu air dibuat sesuai dengan saluran (untuk panjang dan lebarnya). Saluran air berukuran panjang $800 \mathrm{~cm}$, lebar bawah 40 $\mathrm{cm}$, lebar atas $50 \mathrm{~cm}$, tinggi $40 \mathrm{~cm}$ seperti ditunjukkan dalam gambar 2 .

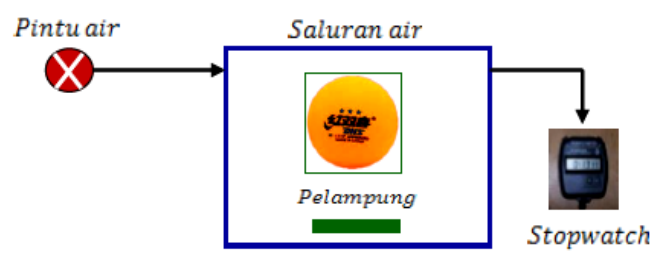

Gambar 1. Skema alat penelitian

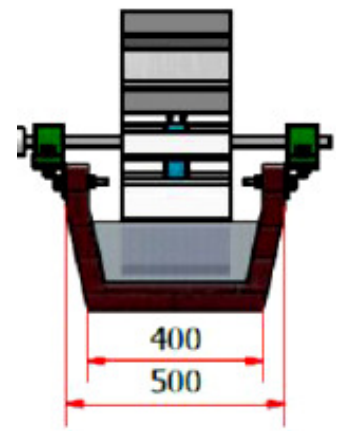

Gambar 2. Tampak depan saluran

\section{Persamaan Yang Digunakan}

Kecepatan aliran air diperoleh dari persamaan (Prayatmo, 2007) :

$v=\frac{l}{t}$

Dimana $v$ adalah kecepatan aliran air $(\mathrm{m} / \mathrm{s}), l$ adalah jarak tempuh pelampung $(\mathrm{m})$, dan $t$ menyatakan waktu tempuh pelampung (detik)

Kecepatan tangensial ialah kecepatan keliling roda air yang diketahui berdasarkan analisa segitiga kecepatan yang dinyatakan dengan persamaan (Sihombing, 2009) :

$U=\frac{\Pi D n_{p}}{60}$

Dimana $U$ adalah kecepatan tangensial roda air $(\mathrm{m} / \mathrm{s}), D$ adalah diameter roda air $(\mathrm{m})$, dan $n_{p}$ menyatakan putaran poros roda air (rpm). Sementara $D$ dapat dicari dengan persamaan sebagai berikut :

$D=D_{\text {velk }}+2 x l_{s}$

Dimana Dvelk adalah diameter velk $(\mathrm{m}), \mathrm{ls}$ dimenyatakan lebar sudu bengkok (m). 
Selanjutnya $n_{p}$ dapat dicari dengan persamaan (Sularso, 2008) :

$n_{p}=\frac{v 60}{2 \Pi r}$

Dimana $v$ adalah kecepatan air $(\mathrm{m} / \mathrm{s}), \mathrm{r}$ merupakan jari-jari roda air $(\mathrm{m})$. Sedangkan $r$ diperoleh dari persamaan sebagai berikut :

$r=\frac{1}{2} D$

Dimana $r$ adalah jari-jari roda air, $D$ menyatakan diameter roda air.

Kecepatan sudut roda air diperoleh dari persamaan (Surbakti, 2009) :

$\omega=\frac{U}{r}$

Dimana $\omega$ adalah kecepatan sudut $(\mathrm{rad} / \mathrm{s}), \mathrm{U}$ adalah kecepatan tangensial $(\mathrm{m} / \mathrm{s}) \quad r$ menyatakan jari-jari roda air $(\mathrm{m})$

Torsi pada poros roda air, dinyatakan dengan persamaan (8) sebagaimana diperoleh dari Sule. et al., (2014) :

$T=F r$

Dimana $T$ adalah torsi pada poros $(\mathrm{Nm}), \mathrm{F}$ adalah gaya pada roda air $(\mathrm{N})$, $r$ adalah jarijari roda air $(m)$. Sementara $F$ dihitung dengan persamaan (Sule, 2011) :

$F=m v$

Dimana $\mathrm{m}$ adalah massa air yang mengalir $(\mathrm{kg} / \mathrm{s}), \quad \mathrm{v}$ adalah kecepatan air $(\mathrm{m} / \mathrm{s})$. Sementara $\mathrm{m}$ dihitung dengan persamaan (Sule, 2011)

$\dot{m}=Q \rho$

Dimana $Q$ adalah volume (debit) air yang mengalir setiap detik $\left(\mathrm{m}^{3} / \mathrm{s}\right), \quad \rho$ adalah kerapatan massa air $\left(\mathrm{kg} / \mathrm{m}^{3}\right)$. Sementara $Q$ bisa dicari dengan persamaan (Munson, 2003) :

$Q=A v$
Dimana A adalah luas penampang terbasahi $\left(\mathrm{m}^{2}\right)$, v menyatakan kecepatan air $(\mathrm{m} / \mathrm{s})$. Sementara A dihitung dengan persamaan (Yusri, 2004) :

$A=d w$

Dimana $A$ adalah luas penampang terbasahi, $d$ menyatakan kedalaman air di saluran, $w$ adalah lebar saluran yang terbasahi.

Daya roda air dapat dicari dengan persamaan Sule. et al., (2014) :

$P_{R a}=T \omega$

Dimana $\mathrm{P}_{\mathrm{Ra}}$ adalah daya roda air (Watt), $\mathrm{T}$ merupakan torsi pada poros roda air (Nm), $\omega$ adalah kecepatan sudut roda air (rad/s).

Kecepatan relative air pada sisi masuk roda air arus bawah (undershot water wheel) dinyatakan dengan persamaan (Sihombing, 2009) :

$W_{1}^{2}=C_{1}^{2}+U_{1}^{2}-2 C_{1} U_{1} \cos \alpha$

Dimana $W_{1}$ adalah kecepatan relative fluida terhadap sudu roda air pada sisi masuk $(\mathrm{m} / \mathrm{s})$, $\mathrm{C}_{1}$ ialah kecepatan absolute fluida masuk $(\mathrm{m} / \mathrm{s}), U_{1}$ adalah kecepatan tangensial / kecepatan keliling sudu roda air yang arahnya searah dengan arah putaran roda air pada sisi masuk.

Kecepatan relative fluida pada sisi keluar roda air arus bawah (undershot water wheel) dinyatakan dengan persamaan (Siahaan, 2009) :

$W_{2}{ }^{2}=C_{2}{ }^{2}+U_{2}{ }^{2}-2 C_{2} U_{2} \cos \alpha$

Dimana $W_{2}$ adalah kecepatan relative fluida terhadap sudu roda air pada sisi keluar $(\mathrm{m} / \mathrm{s})$, $C_{1}$ adalah kecepatan absolute fluida keluar $(\mathrm{m} / \mathrm{s}), \quad U_{1}$ adalah kecepatan tangensial / kecepatan keliling sudu roda air yang arahnya searah dengan arah putaran roda air pada sisi keluar. Sementara besar sudut $\left(\beta_{2}\right)$ yang terbentuk antara $W_{2}$ dan $U_{2}$ pada sisi keluar diperoleh dengan persamaan (Siahaan, 2009):

$\cos \beta_{2}=\frac{U_{2}}{W_{2}} \rightarrow \beta_{2}=a \cos \frac{U_{2}}{W_{2}}$ 


\section{Tempat dan Waktu Penelitian}

Penelitian ini dilakukan di Desa Tamangil Nuhuten Kecamatan Kei Besar Selatan Kabupaten Maluku Tenggara Propinsi Maluku. Penelitian dilakukan pada bulan Agustus dan September 2015.

\section{HASIL DAN PEMBAHASAN Pengukuran Kecepatan Aliran Air}

Gambar 3 menunjukkan proses pengukuran kecepatan aliran air dengan instrument pengujian antara lain pelampung yaitu sebuah bola pingpong, jarak tempuh pelampung adalah $7 \mathrm{~m}$, dan pengukur waktu adalah stopwatch.

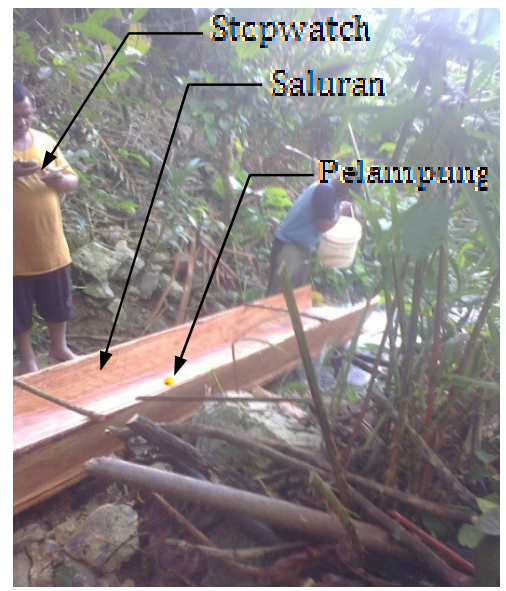

Gambar 3. Pengukuran kecepatan air

Pengukuran kecepatan aliran air sendiri dilakukan selama 2 hari (05-08-2015 dan 1209-2015). Dalam pengukuran waktu tempuh pelampung dilakukan sebanyak 5 kali dan jedah waktu antar tiap pengukuran yaitu 120 menit (2 jam) baik pada tanggal 05-08-2015 maupun tanggal 12-09-2015. Proses ini dilakukan oleh penulis bersama warga yang ditunjuk oleh kepala kampung setempat. Adapun prosedur pengukurannya yaitu sebuah pelampung digerakkan sejauh $7 \mathrm{~m}$ dalam saluran dan seiring itu waktu tempuh pelampung tersebut dicatat pada tabel data yang sudah disediakan.

Tabel 1. Kecepatan air di saluran hasil pengukuran pada tanggal 05-08-2015

\begin{tabular}{ccc}
\hline No & Waktu & Kecepatan air $(\mathrm{m} / \mathrm{s})$ \\
\hline 1 & $08: 00$ & 2,24 \\
2 & $10: 00$ & 2,36 \\
3 & $12: 00$ & 2,33
\end{tabular}

\begin{tabular}{lll}
4 & $14: 00$ & 2,28 \\
5 & $16: 00$ & 2,77 \\
\hline
\end{tabular}

Dengan menggunakan persamaan (1), selanjutnya kecepatan air dihitung dan hasilnya sebagaimana diperlihatkan dalam tabel 1 untuk hari pertama dan tabel 2 untuk hari kedua.

Tabel 2. Kecepatan air di saluran hasil pengukuran pada tanggal 12-09-2015

\begin{tabular}{ccc}
\hline No & Waktu & Kecepatan air $(\mathrm{m} / \mathrm{s})$ \\
\hline 1 & $08: 00$ & 2,60 \\
2 & $10: 00$ & 2,64 \\
3 & $12: 00$ & 2,46 \\
4 & $14: 00$ & 2,46 \\
5 & $16: 00$ & 2,52 \\
\hline
\end{tabular}

Dari tabel 1 dan 2 jelas terlihat adanya perbedaan kecepatan air untuk waktu pengujian setiap 2 jam. Fenomena tersebut cenderung dipengaruhi oleh dua faktor yaitu faktor alam dan manusia. Faktor alam dimana jarak antara pusat jatuhnya air dengan daerah tangkapan air (area pengujian) cukup jauh yaitu $\pm 1 \mathrm{KM}$ ditambah pula jalur aliran air berada di antara pepohonan berukuran kecil sampai besar dengan dasar bebatuan sehingga ada saja partikel-partikel padat yang terhempas ke jalur aliran dan menghambat gerakan air tersebut. Selain itu, faktor manusia dimana aliran air terjun di desa Tamangil Nuhuten setiap hari dimanfaatkan oleh warga untuk keperluan rumah tangga seperti memasak, mencuci, mandi, dan keperluan pertanian, keperluan peternakan dan lain-lain sehingga volume air cenderung tidak menentu.

\section{Diameter roda air}

Dengan persamaan (3), dimana diameter velk ( $D_{\text {velk }}$ ) 0,3 m dan lebar sudu (/s) $0,15 \mathrm{~m}$, maka diperoleh diameter roda air :

$\mathrm{D}=0,6 \mathrm{~m}$

\section{Jari-jari roda air}

Dengan persamaan (5), dimana diameter roda air $(D)=0,6 \mathrm{~m}$, sehingga diperoleh jari-jari roda air :

$\mathrm{r}=0,3 \mathrm{~m}$ 
Putaran poros roda air

Putaran poros roda air $\left(n_{p}\right)$ dapat dihitung dengan persamaan (4). Sementara dari persamaan (4) $v$ dapat dihitung dengan persamaan (1) yang hasilnya sudah ditunjukkan dalam tabel 1 dan 2. Hasil perhitungan putaran poros untuk tiap perubahan kecepatan air ditunjukkan dalam tabel 3 gambar 4 (untuk pengukuran kecepatan per tanggal 05-08-2015) dan tabel 4 gambar 5 (untuk pengukuran kecepatan per tanggal 12-09-2015).

Tabel 3. Hasil perhitungan putaran poros roda air berdasarkan kecepatan air

\begin{tabular}{cccc}
\hline No & Waktu & $\begin{array}{c}\text { Kecepatan air } \\
(\mathrm{m} / \mathrm{s})\end{array}$ & $\begin{array}{c}\text { Putaran Poros } \\
(\mathrm{rpm})\end{array}$ \\
\hline 1 & $08: 00$ & 2,24 & 71,34 \\
2 & $10: 00$ & 2,36 & 75,16 \\
3 & $12: 00$ & 2,33 & 74,20 \\
4 & $14: 00$ & 2,28 & 72,61 \\
5 & $16: 00$ & 2,77 & 88,22 \\
\hline
\end{tabular}

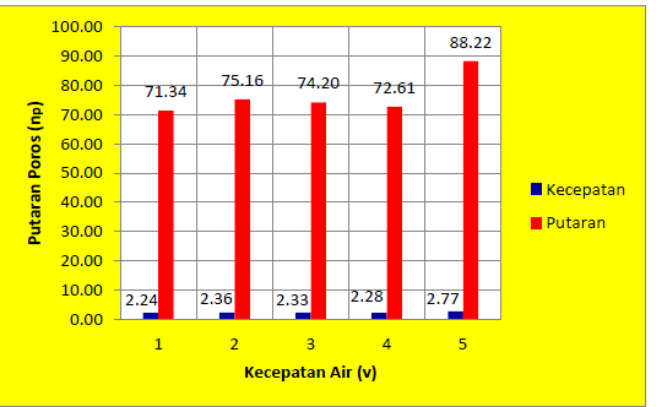

Gambar 4. Hubungan kecepatan air dengan putaran poros roda air

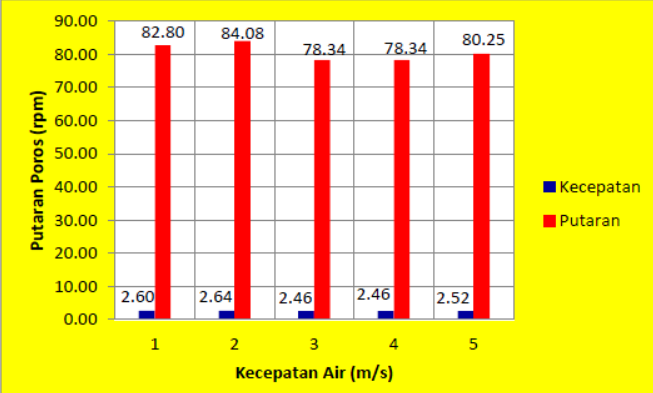

Gambar 5. Perbandingan kecepatan air dengan putaran poros roda air

Tabel 4. Hasil perhitungan putaran poros roda air berdasarkan kecepatan air

\begin{tabular}{cccc}
\hline No & Waktu & $\begin{array}{c}\text { Kecepatan air } \\
(\mathrm{m} / \mathrm{s})\end{array}$ & $\begin{array}{c}\text { Putaran Poros } \\
(\mathrm{rpm})\end{array}$ \\
\hline 1 & $08: 00$ & 2,60 & 82,80 \\
2 & $10: 00$ & 2,64 & 84,08 \\
3 & $12: 00$ & 2,46 & 78,34 \\
4 & $14: 00$ & 2,46 & 78,34
\end{tabular}

\begin{tabular}{cccc}
5 & $16: 00$ & 2,52 & 80,25 \\
\hline & Torsi pada poros roda air \\
Torsi pada poros roda air dapat
\end{tabular}
dihitung dengan persamaan (7). Dari persamaan (7) $F$ dihitung dengan persamaan (8). Sementara dari persamaan (8) $\dot{m}$ dihitung dengan persamaan (9) sedangkan dari persamaan (9) $Q$ dihitung dengan persamaan (10). Sementara dari persamaan (10) $A$ dihitung dengan persamaan (11) Hasil perhitungan torsi ditunjukkan dalam tabel 5 gambar 6 (untuk data per tanggal 05-08-2015) dan tabel 6 gambar 7 (untuk data per tanggal 12-09-2015).

Tabel 5. Hasil perhitungan torsi pada poros roda air

\begin{tabular}{cccc}
\hline No & $\begin{array}{c}\text { Gaya pada } \\
\text { roda air } \\
(\mathrm{N})\end{array}$ & $\begin{array}{c}\text { Jari-jari } \\
\text { roda air } \\
(\mathrm{m})\end{array}$ & $\begin{array}{c}\text { Torsi pada } \\
\text { poros } \\
(\mathrm{Nm})\end{array}$ \\
\hline 1 & 209.49 & 0,3 & 62,85 \\
2 & 165,07 & 0,3 & 49,52 \\
3 & 175,27 & 0,3 & 52,58 \\
4 & 180,67 & 0,3 & 54,20 \\
5 & 228,09 & 0,3 & 68,43 \\
\hline
\end{tabular}

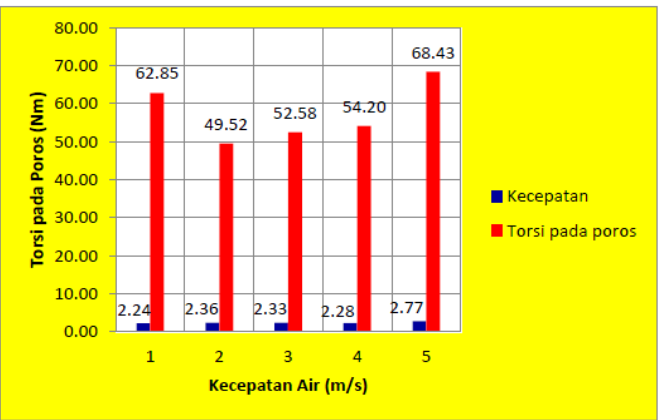

Gambar 6. Hubungan kecepatan air dengan torsi pada poros roda air

Tabel 6. Hasil perhitungan torsi pada poros roda air

\begin{tabular}{cccc}
\hline No & $\begin{array}{c}\text { Gaya pada } \\
\text { roda air } \\
(\mathrm{N})\end{array}$ & $\begin{array}{c}\text { Jari-jari } \\
\text { roda air } \\
(\mathrm{m})\end{array}$ & $\begin{array}{c}\text { Torsi pada } \\
\text { poros } \\
(\mathrm{Nm})\end{array}$ \\
\hline 1 & 169.87 & 0,3 & 50,96 \\
2 & 175,27 & 0,3 & 52,58 \\
3 & 180,67 & 0,3 & 54,20 \\
4 & 225,69 & 0,3 & 67,71 \\
5 & 228,09 & 0,3 & 68,43 \\
\hline
\end{tabular}

Dari tabel (5) dan (6) diperlihatkan bahwa semakin kecil gaya air terhadap roda air maka torsi pada poros juga semakin kecil sedangkan semakin besar gaya air terhadap roda air maka torsi pada poros juga semakin besar. Sementara gaya air yang diterima oleh roda air melalui sudu-sudunya tergantung 
pada kecepatan aliran air dimana dengan berkurangnya kecepatan air maka gaya air semakin kecil namun jika kecepatan air bertambah maka gaya air juga semakin besar.

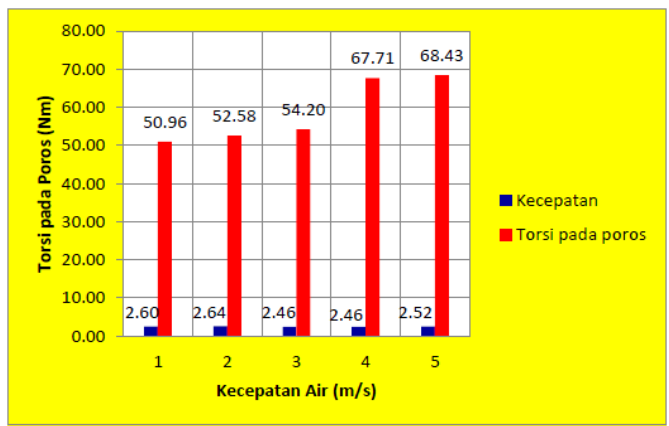

Gambar 7. Hubungan kecepatan air dengan torsi pada poros roda air

\section{Daya Roda Air}

Daya roda air dapat dihitung dengan persamaan (11). Semantara dari persamaan (11) $\omega$ dapat dicari dengan persamaan (6), sedangkan dari persamaan (6) $U$ dihitung dengan persamaan (2). Hasil perhitungan daya roda air, ditunjukkan dalam tabel 7 gambar 8 (untuk data per tanggal 05-08-2015) dan tabel 8 gambar 9 (untuk data per tanggal 12-09-2015).

Tabel 7. Hasil perhitungan daya roda air

\begin{tabular}{cccc}
\hline No & $\begin{array}{c}\text { Torsi pada } \\
\text { poros } \\
(\mathrm{Nm})\end{array}$ & $\begin{array}{c}\text { Kecepatan } \\
\text { sudut roda air } \\
\text { (rad/s) }\end{array}$ & $\begin{array}{c}\text { Daya roda } \\
\text { air } \\
\text { (Watt) }\end{array}$ \\
\hline 1 & 62,85 & 7,47 & 469,49 \\
2 & 49,52 & 7,87 & 389,72 \\
3 & 52,58 & 7,77 & 408,55 \\
4 & 54,20 & 7,60 & 411,92 \\
5 & 68,43 & 9,23 & 631,61 \\
\hline
\end{tabular}

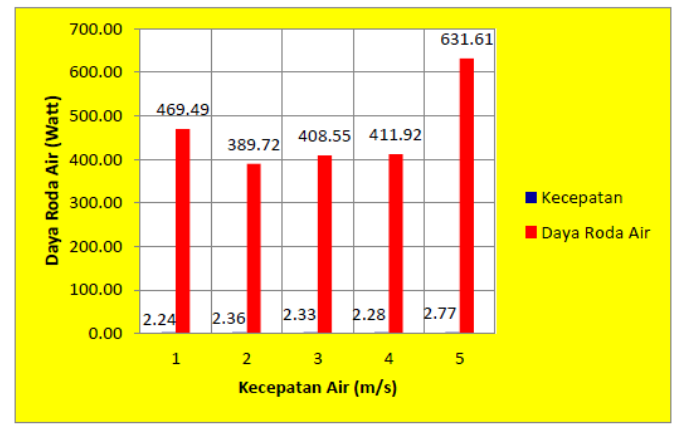

Gambar 8. Hubungan kecepatan air dengan daya roda air
Tabel 8. Hasil perhitungan daya roda air

\begin{tabular}{cccc}
\hline No & $\begin{array}{c}\text { Torsi pada } \\
\text { poros } \\
(\mathrm{Nm})\end{array}$ & $\begin{array}{c}\text { Kecepatan } \\
\text { sudut roda air } \\
(\mathrm{rad} / \mathrm{s})\end{array}$ & $\begin{array}{c}\text { Daya roda } \\
\text { air } \\
\text { (Watt) }\end{array}$ \\
\hline 1 & 50,96 & 8,67 & 441,82 \\
2 & 52,58 & 8,80 & 462,7 \\
3 & 54,20 & 8,20 & 444,44 \\
4 & 67,71 & 8,20 & 555,22 \\
5 & 68,43 & 8,40 & 574,81 \\
\hline
\end{tabular}

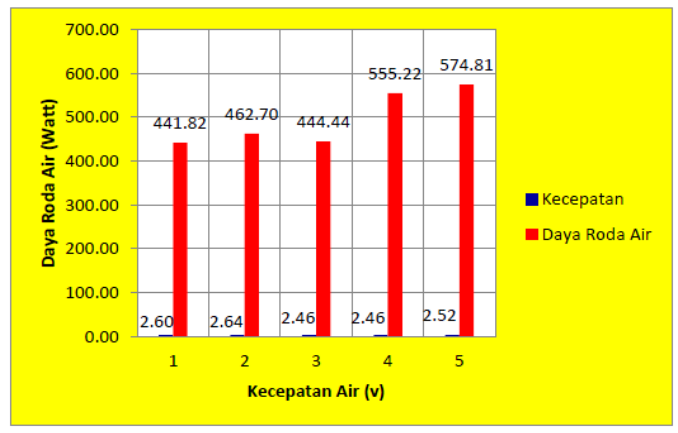

Gambar 9. Hubungan kecepatan air dengan daya roda air

\section{Kecepatan Relatif Air terhadap Sudu}

Pada sisi masuk :

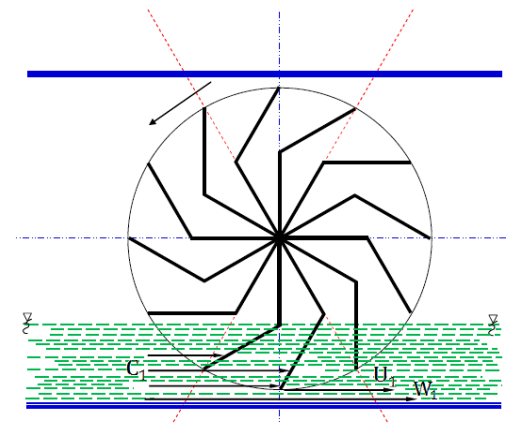

Gambar 10. Analisa kecepatan relatif air terhadap sudu pada sisi masuk

Berdasarkan gambar (4a), kecepatan relative air terhadap sudu pada sisi masuk $\left(W_{1}\right)$ diperoleh dari persamaan (13). Sementara dari persamaan (13) $C_{1}$ merupakan kecepatan absolut air masuk sudu dimana sama dengan kecepatan air masuk sedangkan $U_{1}$ dihitung dengan persamaan (2). Hasil perhitungan kecepatan relative pada sisi masuk sudu untuk tiap perubahan kecepatan air, ditunjukkan dalam tabel 9 (untuk data per tanggal 05-08-2015) dan tabel 10 (untuk data per tanggal.12-09-2015). 
Tabel 9. Kecepatan relative air terhadap sudu pada sisi masuk

\begin{tabular}{cccc}
\hline $\begin{array}{c}\mathrm{v} \\
\mathrm{m} / \mathrm{s})\end{array}$ & $\begin{array}{c}\mathrm{C}_{1} \\
(\mathrm{~m} / \mathrm{s})\end{array}$ & $\begin{array}{c}\mathrm{U}_{1} \\
(\mathrm{~m} / \mathrm{s})\end{array}$ & $\begin{array}{c}\mathrm{W}_{1} \\
(\mathrm{~m} / \mathrm{s})\end{array}$ \\
\hline 2,24 & 2,24 & 2,24 & 0 \\
2,36 & 2,36 & 2,36 & 0 \\
2,33 & 2,33 & 2,33 & 0 \\
2,28 & 2,28 & 2,28 & 0 \\
2,77 & 2,77 & 2,77 & 0 \\
\hline
\end{tabular}

Tabel 10. Kecepatan relative terhadap sudu pada sisi masuk

\begin{tabular}{cccc}
\hline $\begin{array}{c}\mathrm{v} \\
\mathrm{m} / \mathrm{s})\end{array}$ & $\begin{array}{c}\mathrm{C}_{1} \\
(\mathrm{~m} / \mathrm{s})\end{array}$ & $\begin{array}{c}\mathrm{U}_{1} \\
(\mathrm{~m} / \mathrm{s})\end{array}$ & $\begin{array}{c}\mathrm{W}_{1} \\
(\mathrm{Nm})\end{array}$ \\
\hline 2,60 & 2,60 & 2,60 & 0 \\
2,64 & 2,64 & 2,64 & 0 \\
2,46 & 2,46 & 2,46 & 0 \\
2,46 & 2,46 & 2,46 & 0 \\
2,52 & 2,52 & 2,52 & 0 \\
\hline
\end{tabular}

Sebagaimana pada tabel (9) dan (10) jelas diperlihatkan bahwa kecepatan relative air terhadap sudu pada sisi masuk $\left(\mathrm{W}_{1}\right)$ tidak mengalami perubahan sehingga dapat disimpulkan bahwa kecepatan relative air terhadap sudu pada sisi masuk sama besar dengan kecepatan absolute $\left(\mathrm{C}_{1}\right)$.

Pada sisi keluar :

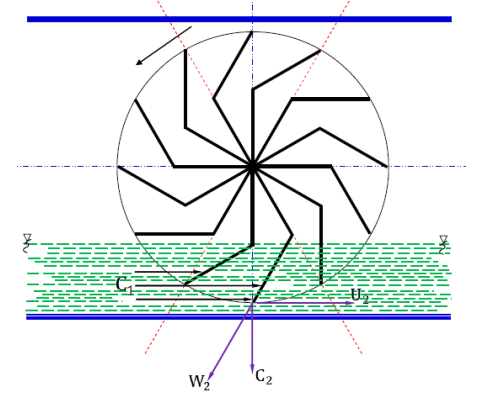

Gambar 11. Analisa kecepatan relatif air terhadap sudu pada sisi keluar

Berdasarkan gambar (4), kecepatan relative air terhadap sudu pada sisi keluar $\left(\mathrm{W}_{2}\right)$ diperoleh dari persamaan (14). Sementara dari persamaan (14), $C_{2}$ merupakan kecepatan absolut air keluar sudu dimana sama dengan kecepatan air masuk sedangkan $U_{2}$ dihitung dengan persamaan (2). Hasil perhitungan kecepatan relative pada sisi keluar sudu untuk tiap perubahan kecepatan air, ditunjukkan dalam tabel 11 (untuk data per tanggal 05-08-2015) dan tabel 12 (untuk data per tanggal.12-09-2015).
Tabel 11. Kecepatan relative air terhadap sudu pada sisi keluar

\begin{tabular}{cccc}
$\begin{array}{c}\mathrm{v} \\
(\mathrm{m} / \mathrm{s})\end{array}$ & $\begin{array}{c}\mathrm{C}_{2} \\
(\mathrm{~m} / \mathrm{s})\end{array}$ & $\begin{array}{c}\mathrm{U}_{2} \\
(\mathrm{~m} / \mathrm{s})\end{array}$ & $\begin{array}{c}\mathrm{W}_{2} \\
(\mathrm{~m} / \mathrm{s})\end{array}$ \\
\hline 2,24 & 2,24 & 2,24 & 3,17 \\
2,36 & 2,36 & 2,36 & 3,34 \\
2,33 & 2,33 & 2,33 & 3,30 \\
2,28 & 2,28 & 2,28 & 3,22 \\
2,77 & 2,77 & 2,77 & 3,92 \\
\hline
\end{tabular}

Tabel 12. Kecepatan relative air terhadap sudu pada sisi keluar

\begin{tabular}{cccc}
$\begin{array}{c}\mathrm{v} \\
(\mathrm{m} / \mathrm{s})\end{array}$ & $\begin{array}{c}\mathrm{C}_{2} \\
(\mathrm{~m} / \mathrm{s})\end{array}$ & $\begin{array}{c}\mathrm{U}_{2} \\
(\mathrm{~m} / \mathrm{s})\end{array}$ & $\begin{array}{c}\mathrm{W}_{2} \\
(\mathrm{~m} / \mathrm{s})\end{array}$ \\
\hline 2,60 & 2,60 & 2,60 & 3,68 \\
2,64 & 2,64 & 2,64 & 3,73 \\
2,46 & 2,46 & 2,46 & 3,48 \\
2,46 & 2,46 & 2,46 & 3,48 \\
2,52 & 2,52 & 2,52 & 3,56 \\
\hline
\end{tabular}

Sebagaimana pada tabel (11) dan (12) jelas diperlihatkan bahwa antara kecepatan absolute air keluar sudu dengan kecepatan relatifnya berbeda. Sama halnya jika ditinjau terhadap kecepatan relative air masuk sudu juga berbeda. Perbedaan antara kecepatan relative air terhadap sudu pada sisi masuk tersebut, selisihnya ditunjukkan dalam tabel 13.

Tabel 13. Perbedaan kecepatan relative air terhadap sudu pada sisi masuk dan keluar

\begin{tabular}{ccc}
\hline $\begin{array}{c}\mathrm{W}_{1} \\
(\mathrm{~m} / \mathrm{s})\end{array}$ & $\begin{array}{c}\mathrm{W}_{2} \\
(\mathrm{~m} / \mathrm{s})\end{array}$ & $\begin{array}{c}\Delta \mathrm{W} \\
(\mathrm{m} / \mathrm{s})\end{array}$ \\
\hline 2,24 & 3,17 & 0,93 \\
2,36 & 3,34 & 0,98 \\
2,33 & 3,30 & 0,97 \\
2,28 & 3,22 & 0,94 \\
2,77 & 3,92 & 1,15 \\
2,60 & 3,68 & 1,08 \\
2,64 & 3,73 & 1,09 \\
2,46 & 3,48 & 1,02 \\
2,46 & 3,48 & 1,02 \\
2,52 & 3,56 & 1,04 \\
\hline
\end{tabular}

Sudut antara $\mathrm{W}_{2}$ dengan $\mathrm{U}_{2}$ (sudut $\boldsymbol{\beta}_{2}$ )

Besar sudut yang terbentuk antara $W_{2}$ dan $U_{2}$ (sudut $\beta_{2}$ ) merupakan implikasi dari segitiga kecepatan berdasarkan kecepatan relative air terhadap sudu pada sisi keluar yang dihitung dengan persamaan (15) dimana hasilnya ditunjukkan dalam tabel 14 .

Tabel 14. Besar sudut $\beta_{2}$

\begin{tabular}{ccc}
\hline $\mathrm{U}_{2}$ & $\mathrm{~W}_{2}$ & $\beta_{2}$ \\
$(\mathrm{~m} / \mathrm{s})$ & $(\mathrm{m} / \mathrm{s})$ & $\left({ }^{\circ}\right)$ \\
\hline 2,24 & 3,17 & 45 \\
2,36 & 3,34 & 45 \\
2,33 & 3,30 & 45,1
\end{tabular}




\begin{tabular}{llc}
$\begin{array}{l}\text { Dinamika Teknik Mesin, Volume 6 No. } 1 \text { Juni } 2016 \\
\text { p. ISSN: 2088-088X, e. ISSN: 2502-1729 }\end{array}$ \\
\hline 2,28 & 3,22 & 44,9 \\
2,77 & 3,92 & 45 \\
2,60 & 3,68 & 45 \\
2,64 & 3,73 & 44,9 \\
2,46 & 3,48 & 45 \\
2,46 & 3,48 & 45 \\
2,52 & 3,56 & 44,9 \\
\hline
\end{tabular}

\section{KESIMPULAN}

Dari hasil pengujian lapangan dan analisis secara teoritis, didapat data sebagai berikut :

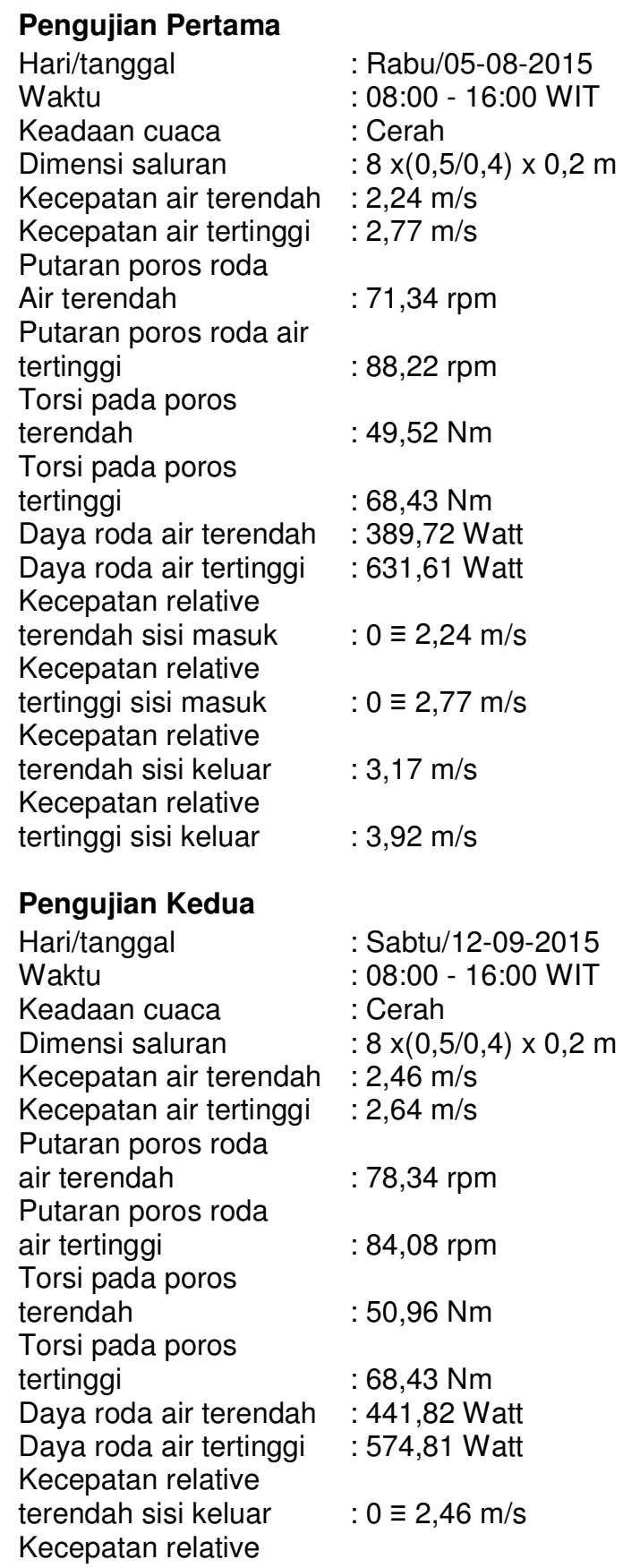

Jamlay, Sule, Hasan: Analisis perilaku aliran terhadap kinerja roda air untuk pembangkit listrik skala pikohidro

tertinggi sisi masuk $\quad: 0 \equiv 2,64 \mathrm{~m} / \mathrm{s}$

Kecepatan relative

terendah sisi keluar $\quad: 3,48 \mathrm{~m} / \mathrm{s}$

Kecepatan relative

tertinggi sisi keluar $\quad: 3,73 \mathrm{~m} / \mathrm{s}$

Dari hasil pengujian dan analisis di atas, maka didapat hasil rata-rata sebagai berikut :

\section{Pengujian Pertama}

Hari/tanggal : : Rabu/05-08-2015

Waktu : 08:00 - 16:00 WIT

Kecepatan air rata-rata $: 2,50 \mathrm{~m} / \mathrm{s}$

Putaran poros roda air

rata-rata : 79,78 rpm

Torsi pada poros roda air

rata-rata $\quad: 58,98 \mathrm{Nm}$

Daya roda air rata-rata $: 510,67$ Watt

Kecepatan relative air

pada sisi masuk sudu

rata-rata $\quad: 2,51 \mathrm{~m} / \mathrm{s}$

Kecepatan relative air

pada sisi keluar sudu

rata-rata $\quad: 3,55 \mathrm{~m} / \mathrm{s}$

\section{Pengujian Kedua}

Hari/tanggal : : Sabtu/12-09-2015

Waktu :08:00 - 16:00 WIT

Kecepatan air rata-rata $: 2,55 \mathrm{~m} / \mathrm{s}$

Putaran poros roda air

rata-rata $: 81,21 \mathrm{rpm}$

Torsi pada poros roda air

rata-rata $\quad: 59,70 \mathrm{Nm}$

Daya roda air rata-rata : 508,32 Watt

Kecepatan relative air

pada sisi masuk sudu

rata-rata $\quad: 2,55 \mathrm{~m} / \mathrm{s}$

Kecepatan relative air

pada sisi keluar sudu

rata-rata $\quad: 3,61 \mathrm{~m} / \mathrm{s}$

Berdasarkan hasil pengujian dan analisia perilaku aliran di saluran sebagaimana di atas, maka disimpulkan bahwa :

1. Bertambahnya kecepatan aliran air akan meningkatkan putaran, torsi, daya roda air serta kecepatan relative air terhadap sudu pada sisi masuk dan keluar.

2. Berkurangnya kecepatan aliran air akan menurunkan putaran, torsi, daya roda air serta kecepatan relative air terhadap sudu pada sisi masuk dan keluar.

3. Hasil pengujian dan analisis terhadap perilaku aliran per tanggal 12-09-2015 adalah yang terbaik dan dianggap layak untuk digunakan dalam perancangan pembangkit listrik skala pikohidro. 
UCAPAN TERIMAKASIH

Penulis mengucapkan banyak terimakasih kepada warga desa Tamangil Nuhuten Kecamatan Kei Besar Selatan yang telah membantu penulis dalam pengambilan data awal mulai dari persiapan lokasi, pembuatan saluran air hingga pengukuran kecepatan air.

\section{DAFTAR PUSTAKA}

Dietzel F., Sriyono D., 1996, Turbin Pompa dan Kompresor, Erlangga, Jakarta.

Prayatmo, 2007, Turbin Air, Graha IImu, Yogyakarta

Siahaan D.H., 2009, Pengujian sudu rata prototipe turbin air terapung pada aliran sungai, Skripsi Teknik Mesin, Universitas Sumatera Utara.

Sihombing E.S., 2009, Pengujian sudu lengkung prototipe turbin air terapung pada aliran sungai, Skripsi Teknik Mesin. Universitas Sumatera Utara.

Sularso, Suga K., 2008, Dasar-dasar Perencanaan dan Pemilihan Elemen Mesin, PT Pradnya Paramita, Jakarta.

Sule L., 2011, Perilaku aliran roda air arus bawah plat bengkok dengan variasi jumlah sudu, Jurnal Teknik Mesin, Universitas Hasanuddin.

Sule L., Wardana I.N.G., Soenoko R., Wahyudi S., 2014, Angled and curved blades of deep-water wheel efficiency, Australian Journal of Basic and Applied Sciences, AENSI Journals.

Yusri, Aidil Z., Asmed., 2004, Analisis daya dan putaran kincir air tradisional sebagai alternatif sumber daya penggerak, Jurnal Teknik Mesin Vol 1, No.2. 